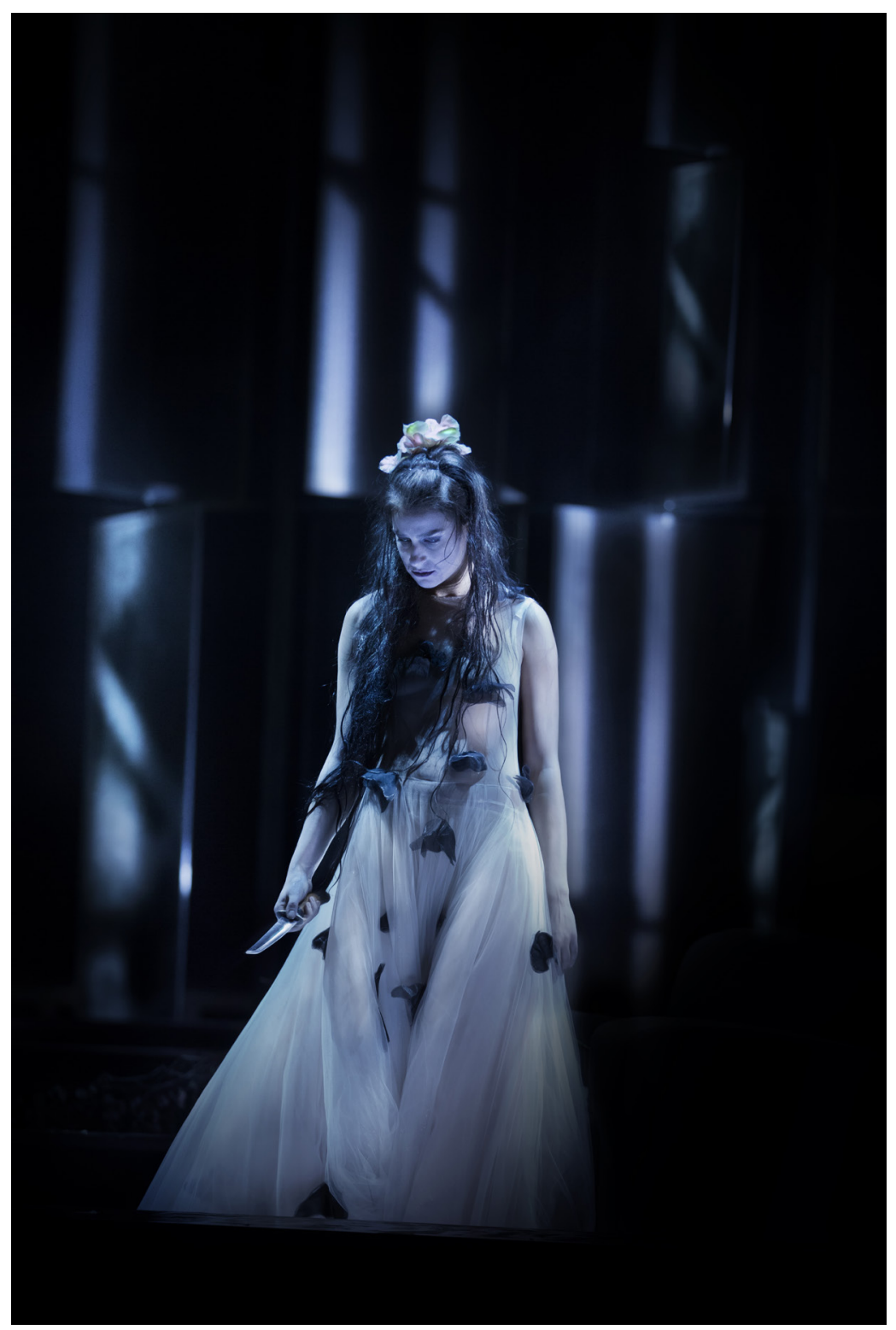

Madama Butterfly (Giacomo Puccini). Asmik Grigorian (Butterfly), Royal Opera, Stockholm, 20I4. Photographer: Marcus Gårder. Copyright CC-BY-NC-ND, Royal Opera, Stockholm. 


\section{Who's Who Underneath the Kimono? Queer Mysteries of M. Butterfly}

For the myths of the East, the myths of the West,

the myths of men, and the myths of women these have so saturated our consciousness that truthful contact between nations and lovers can only be the result of heroic effort.

Those who prefer to bypass the work involved will remain in a world of surfaces, misperceptions running rampant.

This is, to me, the convenient world in which

the French diplomat and the Chinese spy lived.

This is why, after twenty years, he had learned nothing about his lover, not even the truth of his sex.

David Henry Hwang, M. Butterfly

On I I May 1986, The New York Times published a short article on how a French diplomat and a Jíngjù performer with the Beijing opera had been sentenced to six years in prison on spying charges by the People's Republic of China. The curious thing about the incident was that it was surrounded by a secret, forbidden love affair, based on sexual misconception. French diplomat Bernard Boursicot, who was accused of revealing classified information while stationed in Beijing, had fallen in love with Chinese actress, Shi Pei Pu. For twenty years he had labored under the impression that Pu was a woman.

Such misconceptions regarding gender offer a prime opportunity for voyeurism and for stirring up scandal, as was the case here. Playwright Henry Hwang saw in this story the potential for a deconstructed version of Giacomo Puccini's Madama Butterfly with a libretto by Luigi Illica and Giuseppe Giacosa. The libretto

How to cite this book chapter:

Rosenberg, Tiina 2016. Who's Who Underneath the Kimono? Queer Mysteries of M. Butterfly. In: Rosenberg, Tiina Don't Be Quiet, Start a Riot! Essays on Feminism and Performance. Pp. 52-79. Stockholm: Stockholm University Press. DOI: http://dx.doi.org/IO.I 6993/baf.c. License: CC-BY 4.० 
presents an excellent metaphor for a French diplomat who mistakes a Jíngjù performer for a woman. The Frenchman is unaware that all Jíngjù parts are played by men. Hwang also depicts cultural blindness, which he finds entirely predictable: the ignorant "masculine" West dominates and manipulates the submissive "feminine" East. The West is portrayed as a man who never questions his own cultural standing. In turn, Asia is viewed as a woman who adapts to circumstances at any price.

The West thinks of itself as masculine - big guns, big industry, big money - so the East is feminine - weak, delicate, poor ... but good at art, and full of inscrutable wisdom - the feminine mystique. Her mouth says no, but her eyes say yes. The West believes the East, deep down, wants to be dominated - because a woman can't think for herself. ${ }^{2}$

It is instructive to examine Hwang's $M$. Butterfly against the background of post-colonial concepts and queer theory. The play expands its theme so that it pertains to questions of ethnicity as well as gender and sexuality. Hwang questions clichéd Western attitudes toward such matters and toward what has been called the "Orient." Like notions regarding femininity and masculinity, the Orient is a concept of Western perceptions that offers people an opportunity to exempt themselves from their own contradictions.

\section{PINKERTON'S RACIAL OBLIGATION}

Puccini's Madama Butterfly is the cruel tale of a I 5-year-old Japanese geisha named Cio-Cio-San, who is also known as Butterfly. She falls in love and marries a US Marine Lieutenant, Benjamin Franklin Pinkerton. It is the turn of the twentieth century and Pinkerton's boat is anchored in Nagasaki Bay for a few months. To while away the time, Pinkerton decides to marry Butterfly "in the Japanese style," and so a 999-year marriage contract that the man is allowed to renounce every month is drawn up. Pinkerton has no strong feelings about the duration of the marriage. An American consul named Sharpless warns Pinkerton not to toy with Butterfly's emotions. However, Pinkerton brushes him off and proposes a toast to the day when he will have a "genuine" marriage to an American. 
Thus Butterfly and Pinkerton are wed, and soon after the wedding Pinkerton rejoins his company and his ship departs. In Act II, a distraught but faithful Butterfly endures three long years waiting for Pinkerton to return. One day Sharpless visits Butterfly in order to inform her that Pinkerton has remarried in America and is now coming back to Japan. However, Sharpless keeps getting interrupted and is unable to tell Butterfly the whole story. At that moment a wealthy prince named Yamadori arrives and proposes to Butterfly, but she refuses him. When Sharpless advises Butterfly to accept the prince's proposal, she becomes angry and asks him to leave. Soon, however, she relents and surprises Sharpless by introducing her son to him. Sharpless, unaware of the child's existence until now, promises to tell Pinkerton at once. When guns are heard in the harbor saluting the arrival of a ship, Butterfly decorates her home with flowers and, together with her son and her maid, Suzuki, waits through the night for Pinkerton's arrival.

As the curtain rises on Act III, a male choir in Nagasaki is singing. This will be Butterfly's last day. Suzuki and Butterfly stand motionless, waiting for Pinkerton. When he fails to appear, Butterfly goes indoors with her son. Shortly afterward, Sharpless, Pinkerton, and Pinkerton's wife, Kate, arrive at the house. They plan to coax Butterfly into giving up her son to Kate, and they ask Suzuki to help them. Pinkerton, finally grasping the magnitude of his betrayal, leaves the house so that he does not have to face Butterfly. However, Butterfly insists that the boy's father come himself if he wishes to claim his son.

When she was a hopeful, happy bride arriving at her (sham) wedding, Butterfly had wrapped a few keepsakes in the sleeve of her kimono and brought them to the house. One of them was a slim case containing a dagger. The Mikado had once sent this dagger to Butterfly's father, urging him to commit suicide because his family had fallen into ruin. In the wrenching final scene, Butterfly sees no alternative other than to take her life with this same dagger:

Butterfly: Go, Go, and obey my order.

(Makes Suzuki, who is weeping bitterly, rise, and pushes her outside the exit on the left. Suzuki's sobs are heard. Butterfly lights the lamp in front of the Buddha. She bows down. Butterfly remains motionless, lost in sorrowful 
thought. Suzuki's sobs are still heard; they die away by degrees. Butterfly has a convulsive movement. Butterfly goes towards the shrine and lifts the white veil from it, throws this across the screen, then takes the dagger, which, enclosed in a waxen case, is leaning against the wall near the image of the Buddha. Butterfly piously kisses the blade, holding it by the point and the handle with both hands.)

Butterfly: Death with honour is better than life with dishonour.

(Points the knife sideways at her throat.)

(The door on the left opens, showing Suzuki's arm pushing in the child towards his mother: he runs in with outstretched hands. Butterfly lets the dagger fall, darts toward the child, and hugs and kisses him almost to suffocation.)

You? you? you? you? you? you? you?

Beloved Idol!

Adored, adored being,

Fairest flower of beauty.

(Taking the child's head in her hands, she draws it to her)

Though you ne'er must know it

This for you, my love, for you I'm dying,

Poor Butterfly

That you may go away

Beyond the ocean,

Never to feel the torment when you are older,

That your mother forsook you!

(Exaltedly)

My son, sent to me from Heaven,

Straight from the throne of glory,

Take one last and careful look

at your poor mother's face!

That its memory may linger,

one last look!

Farewell, beloved! Farewell, my dearest heart!

Go, play, play.

(Butterfly takes the child, seats him on a stool with his face turned to the left, gives him the American flag and a doll and urges him to play with them, while she gently 
bandages his eyes. Then she seizes the dagger, and with her eyes still fixed on the child, goes behind the screen. The knife is heard falling to the ground, and the large white veil disappears behind the screen. Butterfly is seen emerging from behind the screen; tottering, she gropes her way towards the child. The large white veil is round her neck; smiling feebly, she greets the child with her hand and drags herself up to him. She has just enough strength left to embrace him, then falls to the ground beside him.)

Pinkerton (within, calling): Butterfly! Butterfly! Butterfly! (The door on the right opens violently - Pinkerton and Sharpless rush into the room and up to Butterfly, who with a feeble gesture points to the child and dies. Pinkerton falls on his knees, whilst Sharpless takes the child and kisses him, sobbing.) $)^{3}$

"Con onor muore, chi non può serbar vita con onore," those who cannot live with honour, must die with honour - this is the summation of Puccinis's tragic opera, but it is also the theme of Hwang's play M. Butterfly. Watching Puccini's opera one does not make one want to burst into applause and shout one's admiration aloud. We feel that we are witnessing a ritual in which a woman must be sacrificed. A culturally unacceptable love affair, the opera seems to tell us, can only end with Butterfly's death.

Butterfly's final words call to mind Edward Said's definition of orientalism. Said reprimands Westerners for injecting their own images into a concept they themselves have created and called the "Orient" - an exotic, strange place that becomes known as the Other. According to Said, orientalism is a Western mind-set for "dominating, restructuring and having authority over the Orient." ${ }^{4} \mathrm{He}$ claims that Western culture, by which he means European culture for the most part, "gained in strength and identity by setting itself off against the Orient as a sort of surrogate and even underground self." 5

In Madama Butterfly Puccini appropriated concepts of the East prevalent in his time. By combining exoticism, sexism, and racism in Madama Butterfly, he was able to reinforce imperialism in general. Said shows that at the turn of the twentieth century, the years during which Puccini's opera is set, Orientalists constructed a deeply-rooted form of racism that still characterizes many people's 
attitudes toward Arabs and Jews. The prejudices and values contained in Puccini's opera legitimize Pinkerton's racist views that a "Japanese-style" marriage has no validity and a true marriage can only be entered into with a cultural equal, a white American.

Hwang confronts this subject by thrusting his protagonist, René Gallimard, into a M. Butterfly fantasy sequence between Sharpless and Pinkerton:

Sharpless: Are you serious about this girl?

Pinkerton: I'm marrying her, aren't I?

Sharpless: Yes - with generous trade-in-terms.

Pinkerton: When I leave, she'll know what it's like to have loved a real man. And I'll even buy her a few nylons.

Sharpless: You aren't planning to take her with you?

Pinkerton: Huh? Where?

Sharpless: Home!

Pinkerton: You mean America? Are you crazy? Can you see her trying to buy rice in St. Louis? ${ }^{6}$

The raw tone of the scene suits Pinkerton's character, as presented in Puccini's opera. A more fitting conclusion to Madama Butterfly might have been to have the dagger thrust into Pinkerton. However, that would not have suited the opera's orientalist aesthetics, just as academic orientalism is also founded on Western perceptions of hegemony in the Orient. These notions try to emphasize Western superiority over Eastern regression. As Said writes, "Orientalism depends for its strategy on this flexible positional superiority, which puts the Westerner in a whole series of possible relationships with the Orient without him ever losing the relative upper hand."7 Said continues:

The imaginative examination of things Oriental was based more or less exclusively upon a sovereign Western consciousness out of whose unchallenged centrality an Oriental world emerged, first according to general ideas about who or what was an Oriental, then according to a detailed logic governed not simply by empirical reality, but by a battery of desires, repressions, investments and projections. ${ }^{8}$

Madama Butterfly is filled with notions of Western sovereignty that a little Butterfly-geisha must not challenge or even dream of 
challenging. Her death itself is orientalist and a kind of "feminine" solution: better suicide than overt rebellion.

\section{A vision of the perfect woman}

The dramaturgy of Hwang's M. Butterfly is built around René Gallimard's last days in a Paris jail. He speaks directly to the audience of his life, and his story is punctuated with dream and fantasy sequences in which his Chinese lover, Song Liling, appears among other characters. Scenes from past and present supplement Gallimard's story. Hwang's time frame extends from the Vietnam War and China's Cultural Revolution to the present day. In Act I Gallimard is in I960s Beijing. There his diplomatic career is on the rise and he meets Song Liling. Their relationship develops in Act II. Then in Act III comes Song Liling's revelation and Gallimard reaction as he copes with the truth.

Gallimard had fallen in love with an Eastern stereotype derived from a fantasy: "I, René Gallimard, you see, I have known, and been loved by the perfect Woman." Gallimard's favorite opera is Puccini's Madama Butterfly and he fancies himself a kind of Pinkerton, with Butterfly as his lover. However, at the end of the play he reveals himself, to be, in fact, Butterfly: his feelings of love have been taken advantage of by a Chinese spy, who is revealed to be the true Pinkerton of the scenario.

In the setup Gallimard describes Puccini's Eastern heroine, Butterfly, as a kind of feminine ideal who is both beautiful and brave. Conversely, the presumptive Western hero, Pinkerton, is no more than a mediocre charlatan. Racism and sexism are seamlessly incorporated into Gallimard's outlook on life. In one scene he presents an imagined meeting between Pinkerton and Sharpless:

Pinkerton: Cio-Cio-San. Her friends call her Butterfly. Sharpless: She eats out of my hand!

Sharpless: She's probably very hungry.

Pinkerton: Not like the American girls. It's true what they say about Oriental girls. They want to be treated bad. ${ }^{\circ}$

It is not enough that a woman will eat out of the palm of a man's hand; she must also crave to be abused. Upon her first 
meeting with Gallimard around I960 at the home of the German Ambassador to Beijing, the beautiful Song Liling immediately defies this Orientalist notion. She performs the final scene from Madama Butterfly for the invited guests, and is afterward drawn into a conversation with Gallimard. When he praises her convincing performance, she answers:

Song: Convincing? As a Japanese woman? The Japanese used hundreds of our people for medical experiments during the war, you know. But I gather such an irony is lost on you.

Gallimard: It's a very beautiful story.

Song: Well, yes, to a Westerner.

Gallimard: Excuse me?

Song: It's one of your favorite fantasies, isn't it? The submissive Oriental woman and the cruel white man.

Gallimard: Well, I didn't quite mean ...

Song: Consider it this way: what would you say if a blonde homecoming queen fell in love with a short Japanese businessman? He treats her cruelly, and then goes home for three years, during which time she prays to his picture and turns down marriage from a young Kennedy. Then, when she learns he has remarried, she kills herself. Now, I believe you would consider this girl to be a deranged idiot, correct? But it's because an Oriental who kills herself for a Westerner - ah! You find it beautiful. ${ }^{\text {I }}$

Some time later Song becomes flirtatious and parades before Gallimard all the characteristics of Orientalist femininity: shyness, perturbation, and clemency. This conventionality allows her to manipulate Gallimard, who is starting to enjoy his conquest and begins to feel the first intimations of the absolute power of manhood. ${ }^{12}$

The euphoria that Gallimard describes is very similar to Toni Morrison's finding of an "American" phenomenon in literature whose traits are "new, male, and white." In her long essay "Playing in the Dark," Morrison analyzes how life in a racially segregated society has influenced the work of American authors. Contrary to Said's concept of orientalism, she defines a black individual's 
present alienation in the US as Africanist. An example Morrison gives that may be equated with the power euphoria Gallimard feels is Bernard Bailyn's study of European migrant farmers who become increasingly Americanized. Bailyn describes Scottish scientist and author William Dunbar as overwhelmed by the previously unthinkable power he possesses when, through the slave trade, he finds himself in complete control of another human being's life. Dunbar felt "a sense of authority and autonomy he had not known before, a force that flowed from his absolute control over the lives of others; he emerged a distinctive new man, a borderland gentleman, a man of property in a raw, half-savage world." ${ }^{\text {3 }}$

We may wonder what was going through Gallimard's mind when he met Song Liling. He had received a good education, lived in the sophisticated city of Paris, and enjoyed the privileged status of a diplomat. But none of this seemed to bestow on him the sense of authority or self-determination that only came when he was able to control Song Liling, a feeling the playwright describes as "a rush of power - the absolute power of a man.” According to Morrison:

This force is not a willed domination, a thought-out, calculated choice, but rather a kind of natural resource, a Niagara Falls waiting to drench Dunbar [or Gallimard - T.R.] as soon as he is in a position to assume absolute control. Once he has moved into that position, he is resurrected as a new man, a distinctive man - a different man. And whatever his social status in London [or Paris T.R.], in the New World [or in the Orient - T.R.] he is a gentleman. More gentle, more man. The site of his transformation is within rawness: he is backgrounded by savagery. ${ }^{\mathrm{I}} 4$

When a beautiful woman is finally under Gallimard's control, he cruelly abuses this power, as he readily admits. ${ }^{15}$ Act I ends with the initial love scene, whose associations and staging are realized through butterfly symbolism:

Gallimard: Are you my Butterfly?

Song: What are you saying?

Gallimard: I've come tonight for an answer: are you my Butterfly? 
Song: I don't want to!

Gallimard: Are you my Butterfly?

(Silence; he crosses the room and begins to touch her hair.) I want from you honesty. There should be nothing false between us. No false pride.

Pause.

Song: Yes, I am. I am your Butterfly.

Gallimard: Then let me be honest with you. It is because of you that I was promoted tonight. You have changed my life forever. My little Butterfly, there should be no more secrets: I love you.

(He starts to kiss her roughly. She resists slightly. $)^{16}$

The seduction scene contains direct quotations from Puccini, thus reinforcing Gallimard's position as the dominant Pinkerton, and Song Liling as the submissive Butterfly. When Song accepts the part of Butterfly, Gallimard carries her to the bed. Song remains standing in the dark, fully clothed, reluctant to get undressed, as she is told to do. A chaste Chinese woman does not undress, not even in front of her lover. Gallimard is drunk with power. It fuels his enamorment and sexual pleasure so much that he does not question Song's “Chinese” disposition. Song plays her ideologically orientalist role with mastery. She knows Gallimard has no self-awareness and is so confident in his own cultural standing that he has formed a relationship with her based solely on his personal needs. He enjoys his conquest and smugly states that although "we men may all want to kick Pinkerton, very few of us would pass up the opportunity to be Pinkerton." ${ }^{17}$

The idea of possessing a perfect woman allows Gallimard to consider himself the perfect man. In reality, he only loves himself. The relationship with Song offers him a chance to obtain power, but also an opportunity for sexual exploration without revenge or counter-demands. It is part of Gallimard's hierarchical, heterosexual self-image that he be the one to plunge inside and attain satisfaction. However, at no point does he arouse his submissive partner, regardless of whether he thinks that partner to be a woman or a man. In postcolonial terms, when the "masculine" West controls and manipulates the submissive "feminine" East, the Asian ultimately plays the role of the adaptive "female." I8 
Song Liling and Gallimard's relationship becomes serious and their courtship begins. In Act II Gallimard describes the life that he and Song Liling shared in I960s Beijing:

Gallimard: And so, over the years I961, I962, I963, we settled into our routine, Butterfly and I. She would have prepared a light snack and then, ever so delicately, and only if I agreed, she would start to pleasure me. With her hands, her mouth, too many ways to explain, and too sad, given my present situation. But mostly we would talk. About my life. Perhaps there is nothing more rare to find than a woman who passionately listens. ${ }^{19}$

He enjoys being taken care of. Song plays her part with sovereignty and she listens to Gallimard. In order to tighten her grip on him, she asks, "What would I love most of all? To feel something inside me - something I know is yours." 20 Then Gallimard takes up a simultaneous relationship with an European woman called Renée, his namesake. Western kinship is underscored with the matching first names. René and Renée are cultural siblings, although the European female is direct, confident, and sexually demanding. René Gallimard wonders if a woman can be so unabashedly sexual that it seems almost masculine. ${ }^{21}$ However, despite not really caring very much for Renée, he does not end the affair:

Gallimard: But I kept up our affair, wildly, for several months. Why? I believe because of Butterfly. She knew the secret I was trying to hide. But, unlike a Western woman, she didn't confront me, threaten, even pout. I remembered the words of Puccini's Butterfly:

Song: "Noi siamo gente avvezza / alle piccole cose / umili e silenziose."

Gallimard: "I come from a people / who are accustomed to little / humble and silent." I saw Pinkerton and Butterfly, and what she would say if he were unfaithful.... Nothing. She would cry, alone, into those wildly soft sleeves, once full of possessions, now empty to collect her tears. It was her tears and her silence that excited me, every time I visited Renée. ${ }^{22}$

Song continues to play the part of the perfect Orientalist woman. She knows that the secret Gallimard is trying to keep is that the perfect woman is actually a man because only another man can know what a man truly wants. Gallimard and Renée's 
relationship is about pleasure, which Gallimard feels when he is in control of Song/Butterfly, who remains faithful regardless of what Gallimard/Pinkerton does. An Eastern woman's complete submission sexually arouses Gallimard. That he should give up anything for the sake of a mutual relationship does not even cross his mind. He takes what he wants.

\section{Travesti and theatre}

René Gallimard sees himself as having loved the perfect woman. It is revealed, however, that this woman is actually a man - or is she? As in the case of Gallimard, the male protagonist in Balzac's novella "Sarrasine" is deeply in love with an opera singer named La Zambinella. But La Zambinella is not a woman; he is a castrato. This comes to Sarrasine as a surprise, as he was unaware of the practice of cross-dressing in theatre. ${ }^{23}$

Cross-dressing is a long-standing practice in Asian and Western theatre traditions. Men in ancient Greece and to some extent in Rome performed women's roles. From castratos in opera, and trouser roles in drama, opera, and ballet, to female impersonators in drag shows, contemporary performance, and cinema, cross-dressing characters have appeared both conventionally and experimentally. ${ }^{24}$ The same is true of classical Chinese and Japanese theatre. Seen in historical perspective, the performing arts have never concerned themselves much about mimetic correlation between off-stage gender and the onstage voice and body.

However, cross-dressing and transvestism are not synonymous. Transvestism is used in modern psychology to express the need to dress in the attire conventionally associated with the opposite sex. The word was first used in I9I0 by German sexologist Magnus Hirschfeld. ${ }^{25}$ In theatre the term for disguise is travesti, travesty, or en travesti. The origin of the word is unclear and is sometimes given as Italian, sometimes French. Traditionally, the concept of travesti in theatre and literature refers to concealing one's identity under some sort of a disguise. Its secondary meaning is to ridicule, distort, twist, or parody. Only its tertiary sense signifies to dress as a member of the opposite sex. ${ }^{26}$ Both the French en travesti and the Italian travestire mean to cross-dress, and derive 
from the Latin trans (to cross) + vestis (clothes). Thus, the English term cross-dressing is the equivalent of the Latin and is generally applied to either men dressing in women's clothing or women dressing in men's clothing.

Gallimard is what we would least expect: a culturally ignorant diplomat. He is unaware that the travesti tradition in classical Western and Asian theatre is the norm, not the exception. To this day, classical Asian theatre uses full travesti: an actor painstakingly dresses as a character of the opposite sex, such as in South India's kathakali, and is experienced as such by both cast and audience. Marjorie Garber refers to the eighteenth century Japanese actor Yoshizawa Ayames's statement that only a male actor can create the ideal woman. ${ }^{27}$ Ayame himself was an onnagata, a male actor in Kabuki theatre who specialized in female roles. His claim leads one to believe that if a biological woman had sought a female role in Kabuki, she would have had to learn how to "play a woman" from an onnagata. Biologically speaking, an onnagata is nonfemale, but cannot categorically be said to be male either. The focal point of the travesti role is that an actor is perceived to be a woman. This practice is what Hwang appropriates with irony in M. Butterfly:

Song: I'm an artist, René. You were my greatest ... acting challenge.

(She laughs)

It doesn't matter how rotten I answer, does it? You still adore me. That's why I love you, René. ${ }^{28}$

The objective of male-to-female travesty in Asian theatre is an ideal and the ultimate femininity - a sexualized abstraction that only men are capable of embodying and fully understanding. From a feminist perspective, this "perfect woman" is a suspect character who has been constructed for a man's man. Hwang does not question this issue.

As engaging as M. Butterfly may be dramatically, it is not a very feminist text. The play focuses on male self-pity more than anything else. It offers Gallimard a "dual woman" as the object of his affection: the "masculine" European Renée, and the "feminine" Asian Song, who is ultimately revealed to be a cross-dressed man. 
The play's biologically sound women - Gallimard's wife Helga, his Danish lover and namesake Renée, and his Chinese Communist comrade Chin - are more caricatures than real people. Garber notes that Hwang allows male cross-dressers to symbolize category crisis between sex and gender and East and West. The biological women in the play are examples of "failed" femininity, without their being entitled to the same universality as men. ${ }^{29}$

One can find in Western literature, theatre, and more recently cinema a tendency to internalize travesti roles as a part of the storyline: cross-dressing is not aimed at conjuring up a picture of the opposite gender in the mind of the audience, but the same gender that the actor/singer/dancer otherwise represents. These types of travesti roles are explained and defended by possibilities that the dramaturgy unfolds. Instances of cross-dressing, whatever their intention was, are often followed by misunderstandings, conflicts, or complications brought about by the actions of the actor in disguise.

Very commonly the disguise fools a character of the opposite sex, who takes the other person to be of the gender she or he portrays. Central to the cross-dressing dramaturgy are ensuing difficulties that point toward the "impossible" (read: homosexual) relationship. A central aspect of the irony of drama is that the audience knows more than the characters. ${ }^{30}$ While cross-dressing has most commonly been utilized in comedies, it has also allowed taboos regarding homosexuality to be sidestepped more easily.

\section{The taboos of homosexuality}

Homosexuality is first mentioned at the beginning of Gallimard and Song's relationship in Act I of M. Butterfly. Gallimard stands with Song's letter in his hand and announces that he disapproves of her calling him a "friend": "When a woman calls a man her 'friend,' she's calling him a eunuch or a homosexual.” ${ }^{31}$ René does not like the emasculating tone the word carries. His whole attraction to Song is based on masculine Western superiority, hence the term "friend" displeases him.

According to the rules of René and Song's courtship, Song must never appear nude. Whether satisfying Gallimard orally or anally, 
she is always fully dressed. In his mind, Gallimard wants to interpret their anal intercourse as vaginal, but he never confronts the issue directly. Why this avoidance, although their relationship spans two decades? There is no simple answer. It may be because his relationship with Song is a complicated mix of cultural and gender domination and submission, wishful thinking, homophobia, and love for a projection of his perfect woman in the person of Song.

Gallimard does not initially accept Song's disguise. In Act II he insists that Song undress, resulting in a tense moment. What would Song do if she were to be exposed? And what would Gallimard do if the truth were to come out? However, Song realizes that Gallimard does not necessarily wish to see her naked. What he wants is her submission. She cleverly eases her way out of a particularly tight spot:

Song: No, René. Don't couch your request in sweet words. Be yourself - a cad - and know that my love is enough, that I submit submit to the worst you can give me. (Pause) Well, come. Strip me. Whatever happens, know that you have willed it. Our love is in your hands. I'm helpless before my man. (Gallimard starts to cross the room.)

Gallimard: Did I not undress her because I knew, somewhere deep down, what I would find? Perhaps. Happiness is so rare that our mind can turn somersaults to protect it. At the time I only knew that I was seeing Pinkerton stalking towards his Butterfly, ready to reward her love with his lecherous hands. The image sickened me, pulled me to my knees, so I was crawling towards her like a worm. By the time I reached her, Pinkerton had vanished from my heart. To be replaced by something new, something unnatural that flew in the face of all I'd learned in the world - something very close to love. ${ }^{32}$

With this exchange Hwang connects the Pinkerton subject to Gallimard's proper recognition of his own homosexuality. Now for the first time Gallimard, who is reluctant to discuss the subject of homosexuality, deals with lust, the elusiveness of gender, homosexuality, and love. Gallimard realizes inside himself that everything would fall apart if Song were to disrobe. As for Song, she knows how much Gallimard fears what he dares not verbalize: he is in love with a man. ${ }^{33}$ 
By the time Gallimard makes it to the other side of the room, he has shed his inner Pinkerton entirely, and in its place is filled with something that changes his disposition toward everything he has ever learned. Gallimard pairs this new sensation with the idea of the unnatural, and it reminds him that homosexuality is against nature and therefore morally reprehensible.

If Song has used Gallimard, the political system of China subsequently abuses and despises Song. "Don't forget: there is no homosexuality in China!" says Comrade Chin to Song. ${ }^{34}$ Later in the same Act, when Song states that s/he too has served the revolution, Comrade Chin retorts that such a statement is "bullshit," and that all Song did was wear dresses. She harshly tells Song to "shut up" and to stop "stinking up China" with his "pervert stuff."

Whereas the first half of M. Butterfly deals with Gallimard as the controlling Pinkerton, in the second half Gallimard loses the position of power he has attained during his years in Beijing. His premonitions regarding the political situation in Indochina do not come to pass, and he is recalled to France. In the spirit of the Chinese Cultural Revolution, Song is also sent to France, but as a spy. Thus, s/he is now situated at the source all human pollutants, including homosexuality, come from: the West. ${ }^{35}$

By linking homosexuality and the West, Hwang refers to the typical accusations that are directed at homosexuals. Gay people are said to have learned their sexual inclinations from the perversions and decadence of the West. But same sex relationships are not the only thing that attracts this kind of thinking. In many respects, human rights and the democratic governance model are seen as Western inventions and therefore undesirable. ${ }^{36}$ In China, homosexuality was declared a threat to socialist culture. Despite his work to bring about the political utopia of the People's Republic, Song is declared an enemy of the state and banished to an isolated labor camp. He is also humiliated at his trial and forced to confess his greatest crime of all: homosexuality.

In Paris, stepping once again into the role of Butterfly, Song acts more openly as a spy and manages to recruit René as his courier. René photographs confidential documents that Song then forwards to the Chinese Embassy. Song's "true” identity is dramatically 
revealed in a way typical of the genre. Travesti roles must culminate in a dénouement. In M. Butterfly, the revelation takes place during the trial, when the French police expose the duo. Removing his wig and kimono, the Chinese lover, wearing a Western suit by Armani, stands in front of René. It is the judge who then asks the question that has been on everyone's mind, namely, has Gallimard been aware the whole time that Song is, in fact, a man? Refusing to answer Song articulates two rules instead. Rule One is that men always believe what they want to hear. Rule Two is that the West has some kind of international rape mentality toward the East: "Her mouth says no, but her eyes say yes." 37

Rather than submit in an open political confrontation or make the admission the judge desires, Song finally relinquishes his status as the Oriental Butterfly. Someone in a position of power seldom has to answer direct questions. On the other hand, those in the minority must often justify themselves. Despite his minority status, Song rejects the judge's question because her/his relationship with René Gallimard is too complex to do justice to in a simple answer.

\section{Queer positions}

Is homosexuality the central theme of M. Butterfly? Hwang had intended calling his play Monsieur Butterfly, but ultimately preferred the ambiguity of M. Butterfly..$^{8}$ Just as the letter " $M$ " encompasses both Madame and Monsieur, the line between Madame and Monsieur Butterfly is repeatedly crossed in the drama. The clearest instances are when Song shifts his role from the submissive Oriental Butterfly to the severe Pinkerton. Gallimard's initial status as the superior Western Pinkerton also changes, and he becomes the play's true Butterfly.

However, an unequivocal response to the Madame-Monsieur Butterfly relationship is not given, even at the end of the play when Song Liling becomes "the man" and René Gallimard "the woman." Thus, the problematics of M. Butterfly not only pertain to René and Song's relationship, but to the meaning and relation of gender and sexuality. 
The central aspect of M. Butterfly is the travesti. If we were to focus purely on hetero- or homosexuality and the sadomasochistic interplay between dominant and submissive, we would fail to recognize the more adaptive category that travesti enables. Garber states that the easiest thing to do is declare that Gallimard is in love with a man, but that Gallimard does not want to see or recognize his own homosexuality. ${ }^{39}$ Another simplistic plot summary might be that the calculating Chinese Communist spy deceived Gallimard, but this leaves out the attraction and the love that is central to the story.

The relationship between Song and René, however strange it may seem, is nevertheless mutual. The most provocative aspect of M. Butterfly is probably the idea of the "wrong" sex eliciting genuine feelings of love. This can be ignored if one chooses to interpret Song's gender illusion as a fraud. However, Song and René's ever-growing attraction reveals the reciprocity that underlies it:

Song: We always held a certain fascination for you Caucasian men, have we not?

Gallimard: But that fascination is imperialist, or so you tell me.

Song: Do you believe everything I tell you? Yes. It is always imperialist. But sometimes it is also mutual. ${ }^{\circ}$

A great deal has been written on the subject of cross-dressing across a wide spectrum of discourse. Such investigations are part of queer studies, where the focus is on gender, sexuality, and fluctuations in defining identity. Just as queer can mean odd or strange (in addition to its use as a derogatory term for homosexuality), it can also refer to radical sexual political attitudes that question standardized categories of gender and sexual identification.

"Queer" and "homosexual" are, however, not synonymous. Many argue that "anti-normal" is a more fitting synonym for queer. Judith Butler has urged gender scholars to be "critically queer," in other words, to take upon themselves a systematic disobedience towards traditional identities. The term "queer" is associated with a theoretical and activist attitude that fits the dissonant informal usage of queer as a verb "to ruin," "to destroy." 
For Butler the concept of queer is not to be defined. She feels that the moment its meaning becomes official it will cease to exist. The term is usually construed as meaning non-heterosexual dissonance that did not form a single harmonious whole but suggested instead a mass of tension. ${ }^{4 \mathrm{I}}$ AnnaMarie Jagose summarizes and defines the concept of queer studies as follows:

While there is no critical consensus on the definitional limits of queer - indeterminacy being one of its widely promoted charms its general outlines are frequently sketched and debated. Broadly speaking, queer describes those gestures or analytical models which dramatize incoherencies in the allegedly stable relations between chromosomal sex, gender and sexual desire. Resisting the model of stability - which claims heterosexuality as its origin, when it is more properly its effect, queer has been associated most prominently with lesbian and gay subjects, but its analytic framework also includes such topics as cross-dressing, hermaphroditism, gender ambiguity and gender-corrective surgery. Whether as transvestite performance or academic deconstruction, queer locates and exploits the incoherencies in the impossibility of a 'natural' sexuality; it calls into question even such apparently unproblematic terms as 'man' and 'woman.' 42

Song Liling's travesti figure makes it clear that, as a matter of practicality, it is difficult to situate oneself outside of the female/male divide. Every human is categorized as either a man or a woman. Gender binary logic does not have a term for a human body that is not on one side or another of this dichotomy. Homosexuality confounds the idea that desire must automatically be directed toward members of the opposite sex because desire is an urge that falls outside of the standard heterosexual matrix and is, therefore, considered taboo.

According to Butler, gender and sexuality are neither internal qualities, metaphysical substances, nor straightforward identities. They are discursive, defined by discrimination, and reinforced by the act of stylized repetition. ${ }^{43}$ The heterosexual matrix formalizes what is considered socially acceptable or unacceptable. This matrix calls for a gender system with two clearly defined sexes. Gender is not a form of being, but active imitative doing. Its social stability is founded on repetition and therefore embodies the capacity for 
change. Since reproducing or mimicing anything exactly the same way every time is impossible, each repetition is a challenge to avoid greater or smaller changes. Gender can both consciously and unconsciously be "right" or "wrong." Most people abide by given gender norms, which in turn ensure maintaining and reinforcing their own identities. Gender parodies radicalize the idea that there is only one alternative. "In imitating gender," Butler writes, "drag implicitly reveals the imitative structure of gender itself - as well as its contingency." ${ }^{4}$

Butler considers that both gender and the heterosexuality, that has now become an institution in itself, are social constructions, not natural but political quantities. Gender is constructed performatively through gestures that have generally been construed as consequential and reflective. Performativity does not primarily aim for a result (being), but is directed instead at action (doing), which leads to gender development. Gender recalls Gestus, of which Bertolt Brecht speaks. Gestus manifests itself in social situations, where it acts as a gesture that is representative of ideology or attitude. In other words, gender is mainly an implementation, a kind of performance.

The representation of troubled genders is the driving force behind M. Butterfly. The play does not culminate in the dramatic revelation of Song's "true" identity, but with the incongruity of his male body and feminine gender.

Gallimard: Please. This is unnecessary. I know what you are. Song: Do you? What am I?

Gallimard: A - a man.

Song: You don't really believe that.

Gallimard: Look at you. You're a man!

(He bursts into laughter again)

Song: I fail to see what's so funny!

Gallimard: "You fail to see!" I mean, you never did have much of a sense of humor, did you?

I think it's ridiculously funny that I've wasted so much time on just a man!

Song: Wait. I'm not “just a man.” 
Song: I'm not just any man!

Gallimard: Then, what exactly are you?

Song: I'm your Butterfly. Under the robes, beneath everything, it was always me. Now open your eyes and admit it - you adore me.

(He removes his hand from Gallimard's eyes)

Gallimard: You, who knew every inch of my desires - how could you, of all people, have made such a mistake?

Song: What?

Gallimard: You showed me your true self. When all I loved was a lie. A perfect lie, which you let fall to the ground and now it's old and soiled.

Song: So - you never really loved me? Only when I was playing a part? 45

The issue comes to a head in this exchange. Did Gallimard love a person named Song Liling, or just the image of a person who bore that name? Did he love the gender, or the actual person, who may not be so easily categorized as female or male? Butler warns against interpreting gender as a simple case of roleplay. It is a role that cannot express or conceal its inner "self," regardless of whether the "self" is manifested as a gender or not. Gender is acted out in performance and creates a social fiction by putting forth its psychological content. ${ }^{46}$

Song's question, whether René only loved "her" as a character and not a person, is justified. Travesti places Song outside binary gender logic. A person who embodies a two-fold gender identity does not fit within the "normal" social categories, and is therefore seen as untrustworthy. Garber states that untrustworthiness is traditionally associated with those who disguise themselves for various reasons: actors, diplomats, transvestites, and spies. ${ }^{47}$ In M. Butterfly all of these categories are juxtaposed. The term "spy" is associated with espionage, but also voyeurism.

Ultimately, René chooses the "fantasy" over the "reality." If his Butterfly is not the woman of his dreams, then be will turn into this woman. At the end of M. Butterfly, Song appears as a Chinese Pinkerton, whereas Gallimard, wearing the same wig and kimono 
that Song has discarded, is dressed as the Oriental Butterfly. He applies his make-up, then takes dagger in hand and performs ritual suicide as Puccini's music resounds from the speakers. The concluding scene mirrors the opening one. Song, dressed in male attire, stares at the "woman" in Oriental dress and calls out, "Butterfly? Butterfly?"

Was French diplomat Bernard Boursicot mistaken when he took Shi Pei Pu for a woman and fell in love with her? Was René Gallimard mistaken when he believed Song Liling was a woman and loved her? The play leaves us with a sense of lost happiness. The encounter of Gallimard and Song may have led them to experience things they had never known before, for which neither was prepared. The character of Song offered Gallimard a fantasy that made his world complete. In sustaining that delusion, Gallimard speaks a language that blurs the line between dream and reality. Only in this way can his words hold back the world that closes in on him. Song Liling echoes this sentiment:

One, because when he finally met his fantasy woman, he wanted more than anything to believe that she was, in fact, a woman.

And second, I am an Oriental.

And being an Oriental, I could never be completely a man..$^{8}$

\section{Notes}

I. Hwang, M. Butterfly, "Afterword," Io०.

2. Ibid., III, I, 83 .

3. Puccini, Madama Butterfly, conclusion of Act III.

4. Said, Orientalism, 3. He defines orientalism as follows: "Anyone who teaches, writes about, or researches the Orient - and this applies whether the person is an anthropologist, sociologist, historian, or philologist - either in its specific or its general aspects, is an Orientalist, and what he or she does is Orientalism.”

5. Ibid., 3. Said claims that "to speak of Orientalism is to speak mainly of a British and French cultural enterprise.... Orientalism derives from a particular closeness experienced between Britain and France 
and the Orient, which until the early nineteenth century had really meant only India and the Bible lands. From the beginning of the nineteenth century until the end of World War II France and Britain dominated the Orient and Orientalism; since World War II America has dominated the Orient, and approaches it as France and Britain once did."

6. Hwang, M. Butterfly, I, 4, 6-7.

7. Said, Orientalism, 7 .

8. Ibid., 7-8.

9. Hwang, M. Butterfly, I, 3-4.

Io. Ibid., I, 6, 6 .

I I. Ibid., I, 6, I7.

I2. Ibid.

I3. Morrison, Playing in the Dark. Her source is Bernard Bailyn, Voyagers to the West: A Passage in the Peopling of America on the Eve of the Revolution (New York: Knopf, I986).

I4. Ibid., 6I.

I 5. Hwang, M. Butterfly I, I I, 36.

I6. Ibid., I, I3, 3-40.

I7. Ibid., II, I, 42.

I 8. Kondo, “M. Butterfly,” I7; see also Spivak, Other Asias. During the last fifteen years scholarship on postcolonial theory and queer theory has been increasingly published. See Hawley, Postcolonial Queer: Theoretical Intersections; Puar, Terrorist Assemblages.

I9. Hwang, M. Butterfly, II, 5, 49.

20. Ibid., II, 6, 5 I.

2I. Ibid., II, 6, 54 .

22. Ibid., II, 6, 56 .

23. Roland Barthes is referring to Balzac's "Sarrasine" in $S / Z$.

24. See Baker, Drag: Bullough \& Bullough, Cross Dressing; Garber, Vested Interests; Ferris, Crossing the Stage; Gilbert \& Gubar, 
Sexchanges; Senelick, The Changing Room. See also Abbate, In search of Opera; André, Voicing Gender: Castrati, Travesti, and the Second Woman in Early Nineteenth-Century Italian Opera; Blackmer \& Smith, En Travesti.

25. Magnus Hirschfeld, Die Transvestiten. Eine Untersuchung über den erotischen Verkleidungstrieb (Berlin: Pulvermacher, I9 Iо). See also the same author's Sexuelle Zwischenstufen. Das männliche Weib und der weibliche Mann (Bonn: Marcus \& Weber, I9I 8). For a transvestite, female clothing has a fetishistic function. It is an implication of a heterosexual or homosexual man's “female identity." Transsexualism, on the other hand, is when a man feels himself to be a woman or when a woman feels herself to be a man. D. O. Cauldwell first began using this term, and Harry Benjamin popularized it in the I960s.

26. “Travesti,” Enciclopedia dello Spettacolo, Roma: Casa Editrice Le Maschere, I954-I962. For a discussion of how the concept of travesti originally referred only to disguising oneself, see André, Voicing Gender; Hov, Kvinnerollene, I I-I 2; Rosenberg, Byxbegär.

27. Garber, Vested Interests, 245. See also Leonard Cabell Pronko, Theater East and West (Berkeley: University of California Press, 1967).

28. Hwang, M. Butterfly, II, 7, 63 .

29. Garber, Vested Interests, 249.

30. In the Howard Hawks classic comedy Bringing Up Baby (1938), Aunt Elizabeth (Mary Robson) asks Dexter (Cary Grant), who is clad in a women's dressing robe adorned with feathers, if he customarily dresses in such attire. Grant spreads his arms and yells: "No! I've just gone gay . . . all of a sudden!" The scene reflects two stereotypes of a man in women's clothes: on the one hand, all the associations of gay culture tied to cross-dressing, drag, voguing performances, and pop icons such as David Bowie, Boy George, and The New York Dolls; and on the other, the comedic cross-dressed characters on stage, television, and in the movies. Charley's Aunt, Tootsie, Mrs. Doubtfire, Dame Edna, and Lily Savage are only a few examples of cross-dressing in modern cinema.

3. Hwang, M. Butterfly, I, I I, 35 .

32. Ibid., II, 7, 60.

33. From this point on in the text, Song Liling shall be referred to as "he." 
34. Hwang, M. Butterfly, II, 4, 48 .

35. Ibid., II, I I, 72.

36. See Blackwood \& Wieringa, Female Desires; Bullough \& Bullough, Cross Dressing.

37. Hwang, M. Butterfly, III, I, 83 .

38. Ibid., "Afterword," 95.

39. Garber, Vested Interests, 236.

40. Hwang, M. Butterfly, I, 8, 22.

4I. Rosenberg, Byxbegär.

42. Jagose, Queer Theory.

43. Butler, Gender Trouble, I24.

44. Ibid., I 37 .

45. Hwang, M. Butterfly, III, 2, 87-88.

46. Butler, "Performative Acts," 279.

47. Garber, Vested Interests, 256.

48. Hwang, M. Butterfly, III, I, 83 .

\section{Works Cited}

Abbate, Carolyn. In Search of Opera. Princeton: Princeton University Press, 200I.

André, Naomi. Voicing Gender: Castrati, Travesti, and the Second Woman in Early Nineteenth-Century Italian Opera. Bloomington: Indiana University Press, 2006.

Baker, Roger. Drag: A History of Female Impersonation in the Performing Arts. London: Cassell, I994.

Barthes, Roland. S/Z. Translated by Richard Miller. New York: Hill \& Wang, I974.

Blackmer, Corinne E., and Patricia Juliana Smith, eds. En Travesti: Women, Gender Subversion, Opera. New York: Columbia University Press, I995. 
Blackwood, Evelyn, and Saskia E. Wieringa, eds. Female Desires: Same-Sex Relations and Transgender Practices Across Cultures. New York: Columbia University Press, I999.

Bullough, Vern, and Bonnie Bullough. Cross Dressing: Sex, and Gender. Philadelphia: University of Pennsylvania Press, I993.

Butler, Judith. Gender Trouble: Feminism and the Subversion of Identity. New York: Routledge, I990.

. "Performative Acts and Gender Constitution: An Essay in Phenomenology and Feminist Theory." In Performing Feminisms: Feminist Critical Theory and Theatre, edited by Sue-Ellen Case, 270-28 I. Baltimore: Johns Hopkins University Press, I990.

Ferris, Leslie, ed. Crossing the Stage: Controversies on CrossDressing. London: Routledge, I993.

Garber, Marjorie. Vested Interests: Cross-Dressing and Cultural Anxiety. New York: Routledge, I992.

Gilbert, Sandra M. and Susan Gubar. No Man's Land: The Place of Woman Writer in the Twentieth Century. New Haven: Yale University Press, I989.

Hawley, John C., ed. Postcolonial Queer: Theoretical Intersections. New York: State University of New York, 200I.

Hov, Liv. Kvinnerollene $i$ antikkens teater - skrevet, spilt og sett av men (Women's Roles in Ancient Theatre - Written, Played, and Viewed by Men). Dissertation. University of Oslo, 1998.

Hwang, David Henry. M. Butterfly, with an Afterword by the Playwright. New York: Plume, I988.

Jagose, Annamarie. Queer Theory: An Introduction. New York: New York University Press, 1996.

Kondo, Dorinne K. “M. Butterfly: Orientalism, Gender, and a Critique of Essentialist Identity.” Cultural Critique, Fall I990: 5-29.

Morrison, Toni. Playing in the Dark: Whiteness and the Literary Imagination. Cambridge, MA: Harvard University Press, I992.

Puar, Jasbir K. Terrorist Assemblages. Homonationalism in Queer Times. Durham: Duke University Press, 2007. 
Puccini, Giacomo, Madama Butterfly. I904. Original Italian text by Luigi Illica and Giuseppe Giacosa. English translation taken from R.H. Elkin, Libretto for Madama Butterfly: An Opera in Three Acts (English and Italian Edition). Translated by Ruth and Thomas Martin. New York: Metropolitan Opera Record Club, 1957.

Rosenberg, Tiina. Byxbegär (Desiring Pants). Göteborg: Anamma Böcker, 2000.

Said, Edward. Orientalism. London: Penguin, I995 [I978].

Senelick, Laurence. The Changing Room: Sex, Drag, and Theatre. London: Routledge, 2000.

Spivak, Gayatri Chakravorty. Other Asias. New Jersey: WileyBlackwell, 2007. 